psychotherapist at Runwell, Rochford and Basildon Hospitals, where he developed the psychodynamic psychotherapy services for the local communities. He was also consultant to the Invalid Children's Aid Association School and Manor House School for children with language and communication problems and he was advisor to the National Association for Mental Health on residential establishments. In the early 1980s, he was briefly Associate Professor of Psychiatry at the University of Ottawa and in the early 1990s he led the group therapy programme at the Department of Psychotherapy at University College London Hospital.

He wrote a number of papers on psychopharmacological subjects and more recently a chapter on stresses in psychotherapists in the National Health Service (NHS) in the book Stress in Psychotherapists (Varma, 1997). After retiring from the NHS he continued private work.

He was a warm and lively man whose clinical approach to psychoanalytic psychotherapy was open minded. He was influenced by the 'independent' group of psychoanalysts in the British Psychoanalytical Society and was a member of a Freud-Jung study group.

He was married twice, first to Shelagh de Fane Morgan and then to Marjorie Wallace. He is survived by both, as well as by his seven children and Anna Teicher, his partner of the past 20 years. He died in November 2011.

Peter Shoenberg

doi: 10.1192/pb.bp.112.039842

\section{Professor Phil Seager}

\section{Formerly Professor of Psychiatry, University of Sheffield and Director of the National Health Service Health Advisory Service}

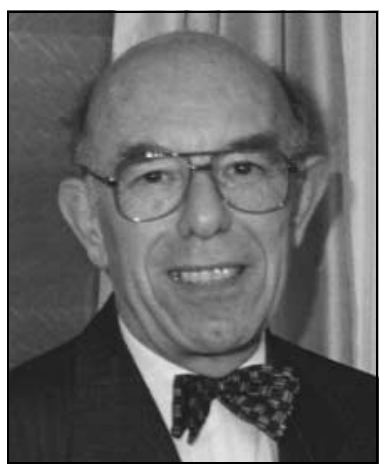

Phil Seager was an eclectic independent thinker under whose directorship the Health Advisory Service (HAS) brought about nationwide improvements in psychiatric services. His recommendations on behalf of the HAS were not only perceptive and incisive, but sensible and feasible.

He was an inspiring leader an accomplished academic and a talented clinician. He

published widely on many different subjects including a landmark paper on suicide in Bristol, carried out jointly with Anthony Flood. The article remains a classic of its kind and is still worthy of careful re-reading as a comprehensive clinical and demographic account of suicide in the city. The study was the first to draw attention to the way in which some suicidal individuals alienate themselves from effective help because of their challenging behaviour.

His other research interests included the effectiveness of electroconvulsive therapy, clinical aspects of postpartum mental illness, the menopause and abortion, comparisons of hospital and community treatment, and electrical aversion therapy in compulsive gamblers. He also published papers on the use of audiovisual aids and telephone conferences and a textbook on psychiatric nursing.

Phil was born in Swansea in 1926. He qualified in medicine in 1949 and completed his pre-registration training in Cardiff. After 2 years of National Service in the RAF based in Singapore and Ceylon, he returned to take up psychiatric training in the United Bristol Hospitals and the Belmont Hospital. During this time he won the Gaskell Gold Medal. He then won a Fulbright Scholarship and spent a year in lowa, in the USA. Soon after his return to Bristol he gained his MD. After 3 years as consultant psychiatrist at St Mary Abbott's and Banstead Hospitals in London and Surrey he moved to Sheffield to become Senior Lecturer in the Department of Psychiatry, where eventually he was appointed to a Personal Chair. During the final 3 years before his retirement he was seconded to the post of Director of the National Health Service (NHS) Health Advisory Service. Throughout the whole of his retirement he continued to offer help at St Luke's Hospice in Sheffield.

He was a prominent figure in the NHS, both in Sheffield and throughout the Trent region. He served on the hospital advisory committee at Rampton Hospital, participated in the work of mental health review tribunals, and was regional advisor for the Royal College of Psychiatrists. He was also President of the South Yorkshire Medico-Legal Society. His enduring interest in both nursing and medical education is revealed by his membership of the General Nursing Council, the English National Board for Nursing, Midwifery and Health Visiting.

He took much interest in the production of videotapes as educational aids for medical students and psychiatric trainees, and introduced psychiatric attachments in medical pre-registration posts. For some years, he advised the University of Singapore in its postgraduate training in psychiatry. He was Member of Council of the Association for Medical Education in Europe, and won a scholarship to review the teaching of emotional aspects of medicine in northern Europe. In 1992, he was elected Vice-President of the Royal College of Psychiatrists and at various other times he was member of Council, Sub-Dean, member of the Court of Electors and the Examinations Subcommittee, member of the Executive and Finance Committee, Secretary of the Education Committee and Chairman of the Nursing Committee.

Colleagues remember how rewarding it was to meet Phil Seager; his genial manner and broad smile, together with the inevitable colourful bow tie could help ease the most fraught of situations. In no small measure his remarkable effectiveness as a clinician was due to his tolerant and non-judgemental approach, which earned him great respect from colleagues and patients alike. Those close to him also soon realised that his gentle manner belied a fierce determination to stand up for and promote those principles that were dear to him.

His thorough grounding in the realities of face-to-face care of the mentally ill, both in a traditional mental hospital setting and in the general hospital, meant that he was very much aware of the many problems and dilemmas that clinicians face day to day. He was particularly helpful in supporting colleagues whether by listening, advising or even taking over the care of difficult clinical problems. Greatly appreciated too was his work with Alcoholics Anonymous and Gamblers Anonymous. 
His zest for life was reflected in a wide variety of activities outside the workplace. At one stage he was president of his local synagogue and for many years he enjoyed walking the hills of the Peak District. He was an enthusiastic amateur baker (specialising in bagels) and a skilled rug maker. He was a devoted family man. Predeceased by his first wife Renee, he is survived by his second wife Marcia and his daughter Sharon. He died in 2011 aged 85.

Alec Jenner, Gethin Morgan

doi: $10.1192 / p b . b p .112 .039859$

\section{Dr Tomma Muhsin MBChB MRCPsych}

Formerly Consultant Psychiatrist for Older People and Lead Consultant for Older People and Adult Mental Health Services in North Lincolnshire, Rotherham, Doncaster and South Humber NHS Foundation Trust (RDaSH)

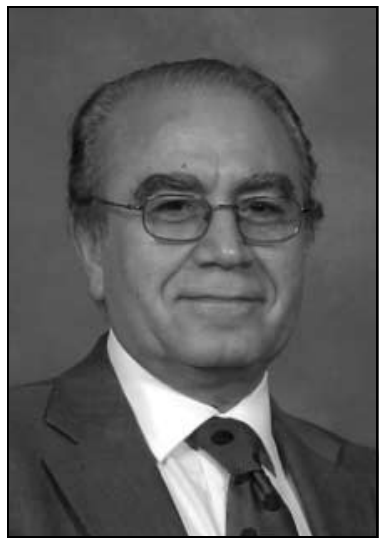

In recognition of Dr Tomma Muhsin's efforts in rebuilding healthcare services in Iraq, a postgraduate lecture hall in the new postgraduate centre at $\mathrm{Ibn}$ Rushd Teaching Hospital in Baghdad was named after him. He returned to his homeland several times with the purpose of improving provision for patients with mental illness; he also visited Kurdistan in the north and Basrah in the south. The lecture theatre in Baghdad was a tribute to his sterling efforts to a cause he cared about very deeply.

Tomma was born in 1950 in Baghdad and went to medical school there in 1968. Between studying and attending lectures he notably chaired an outlawed, left-wing students' union committee. He did his house jobs in Basrah and, after completing his military and rural services, he held a senior residency job at Ibn Rushd Hospital, the main acute psychiatric hospital in Baghdad. In 1981, he came to the UK to complete his training, but after finishing his psychiatric rotation at the Royal Free Hospital in London he decided to stay.

Tomma took great pride in his work for the National Health Service (NHS), both as a clinician and as a medical manager; he later became clinical director of adult and older peoples' mental health services in North Lincolnshire. His loyal service to the area was posthumously recognised by Rotherham Doncaster and South Humber NHS Foundation Trust, who dedicated a garden to him in the acute mental health unit in Scunthorpe.

Tomma was described by friends and colleagues as someone who was always fun to be with. He had a cheerful disposition, a relaxed and unrushed approach, and this made people feel at ease around him. Besides his work, Tomma had many other interests. He was a keen traveller and along with his wife he visited various parts of the world up until a couple of months before his death. He was interested in the history of the Middle East and Iraq in particular and was an avid reader of books and articles on the subject. He was proud of his Iraqi roots. He was a founder member of the Iraqi Mental Health Forum, a professional association of Iraqi expatriate mental health professionals in the UK. He was a past executive committee member and chair of this forum. He was also a member of the Iraqi Subcommittee of the Royal College of Psychiatrists.

Tomma's death has been a great loss to his many friends and colleagues. It has also been a great loss to mental health services in North Lincolnshire and to the mental health community both in the UK and in Iraq. His death will be felt most by his family. He died in November 2011 and is survived by his wife Amal, daughters Zeena and Huda, son Salam and grandson Zak.

Riadh Abed

doi: 10.1192/pb.bp.112.039792 